\title{
Biomarkers in Transplantation Medicine: Prediction of Pharmacodynamic Drug Effects
}

\author{
Markus J. Barten Jan F. Gummert \\ Department of Cardiac and Thoracic Surgery, University Hospital Jena, Friedrich-Schiller University Jena, Germany
}

\section{Key Words}

Immunosuppressive drugs . Whole blood .

Pharmacodynamics - Flow cytometry - T cells .

Dendritic cells · Biomarkers · Transplantation

\section{Summary}

Conventional therapeutic drug monitoring based on measuring of blood concentrations (pharmacokinetic) is important in the clinical management of immunosuppressive therapy in transplantation medicine. Since rejection or infection occurs at irregular drug concentrations, immunosuppressive drug therapy is often empiric and prophylactic in nature. In addition, blood immunosuppressant levels are only indirect predictors of the pharmacologic effects on immune cells (pharmacodynamic) because, due to the genetic heterogeneity, the immune systems of the transplant recipients are not equally sensitive to drug effects. Therefore, therapeutic drug monitoring requires the application of reliable and effective methods to study the pharmacodynamic variability by direct measurements of drugs effects on immune cell functions. Against this background we developed assays which are based on whole blood, flow cytometry and biomarkers of diverse functions of $T$ cells and of dendritic cell subsets. These biomarker assays allow us to differentiate between synergistic and antagonistic pharmacodynamic effects of an immunosuppressive drug combination therapy in vitro and to predict the pharmacodynamic drug effects in heart-transplanted recipients. Such a pharmacodynamic drug monitoring based on biomarkers may offer the opportunity to complete conventional therapeutic drug monitoring and, therefore, to tailor immunosuppressive therapy more individually.

\author{
Schlüsselwörter \\ Immunsuppressive Medikamente - Vollblut . \\ Pharmakodynamik · Durchflusszytometrie - T-Zellen . \\ Dendritsche Zellen · Biomarker · Transplantation
}

\section{Zusammenfassung}

Das konventionelle therapeutische Medikamenten-Monitoring basierend auf der Messung von Blutkonzentrationen ist wichtig für das klinische Management einer immunsuppressiven Therapie in der Transplantationsmedizin. Da Abstoßungen und Infektionen oft unter irregulären Medikamentenkonzentrationen auftreten, ist die immunsuppressive Therapie oft nur von empirischer und prophylaktischer Natur. Zusätzlich sind die Blutwerte der Immunsuppressiva nur indirekte Prädiktoren des pharmakologischen Effekts auf Immunzellen (Pharmakodynamik), weil aufgrund der genetischen Verschiedenheit die Immunsysteme von transplantierten Empfängern nicht die gleiche Sensitivität in Bezug auf die Medikamenteneffekte haben. Deshalb erfordert ein therapeutisches Medikamenten-Monitoring die Anwendung von verlässlichen und effektiven Methoden, um durch direkte Messung des Medikamenteneffekts auf die Immunzelle die pharmakodynamische Verschiedenheit zu studieren. Vor diesem Hintergrund haben wir Assays entwickelt, die auf Vollblut, Durchflusszytometrie und Biomarkern von verschiedenen Funktionen von T-Zellen und dendritischen Zelluntergruppen aufgebaut sind. Diese Biomarker erlauben uns, zwischen synergistischen und antagonistischen pharmakodynamischen Effekten einer immunsuppressiven Kombinationstherapie in vitro zu differenzieren und den pharmakodynamischen Medikamenteneffekt in herztransplantierten Empfängern zu bestimmen. Ein pharmakodynamisches Medikamenten-Monitoring basierend auf Biomarkern könnte es ermöglichen, das konventionelle therapeutische Medikamenten-Monitoring zu komplettieren und somit die immunsuppressive Therapie individueller zu gestalten.

\begin{tabular}{|c|c|}
\hline KARGER & (C) 2007 S. Karger GmbH, Freiburg \\
\hline $\begin{array}{l}\text { Fax +4976145207 } 14 \\
\text { E-mail Information@Karger.de } \\
\text { www.karger.com }\end{array}$ & $\begin{array}{l}\text { Accessible online at: } \\
\text { www.karger.com/tmh }\end{array}$ \\
\hline
\end{tabular}

Dr. med. Markus J. Barten

Department of Cardiac and Thoracic Surgery, University Hospital Jena Friedrich-Schiller University Jena 07747 Jena, Germany Tel. +49 3641 93229-01, Fax -02

E-mail markus.barten@med.uni-jena.de 


\section{Introduction}

Despite the introduction of new sampling strategies for measuring drug concentrations and despite the use of new potent agents, therapeutic drug monitoring after organ transplantation is still challenging in the clinical routine. The small therapeutic window of all currently available drugs requires a monitoring which is done by routinely measurements of blood or plasma drug concentrations (pharmacokinetic) to avoid toxic drug levels and to monitor recipients' compliance. However, the limitations of the pharmacokinetics to measure pharmacodynamic drug effects has prevented immunosuppressive therapy from being administered at high levels 'pre-emptively' for those recipients who require more intense immunosuppression, leading to rejection and increased risk of late graft failure [1]. In addition, combinations of immunosuppressive drugs are associated with synergistic and antagonistic effects. Moreover, inter-subject variability may occur with respect to the sensitivity to suppression of immune function. Thus, in order to balance immunosuppression, one current goal of transplantation medicine is to explore peripheral biomarkers of relevant immune events to monitor the immunosuppressive status of recipients for prediction of the pharmacodynamic drug effects [2].

In predictive medicine $[3,4]$ the potential of biomarkers for cardiovascular diseases and clinical outcome after cardiac surgery with cardiopulmonary bypass have been investigated [5-7]. In earlier studies [8-10] we evaluated the potential of biomarkers of $\mathrm{T}$ cell functions in an experimental animal model. We determined the relationship between the pharmacodynamic effects and both the pharmacokinetics and the drug doses. Furthermore, we observed that the changes of T cell function over time in immunosuppressed allograft recipients correlated highly with the severity of histopathologic events within the allograft tissue [8]. In addition, we detected new mechanisms of drug action and could distinguish between synergistic, additive or antagonistic drug interactions after combination therapy $[9,10]$.

This article highlights our results of using biomarkers of $\mathrm{T}$ cell and dendritic cell functions in human in vitro studies and of clinical studies in heart-transplanted (HTx) recipients in the context of the current literature.

\section{Methods}

Our pharmacodynamic assays rely on the following methods: i) whole blood as the matrix of choice to reflect the effects of immunosuppressive drugs in vivo; ii) flow cytometry analysis; iii) biomarkers of immune cell functions.

We used whole blood instead of the generally used purified cells or isolated cell lines as the matrix for our assays for various reasons [11]: i) the use of whole blood requires 10- to 100fold lower sample volumes and shorter preparation times compared to techniques that rely on purified cells or cell lines; ii) nonuniform cell loss during separation alters cell populations and disturbs cell-cell interactions; iii) whole blood includes plasma components and red cells to which drugs bind and into which they distribute; iv) most important, a dissociation of drug from its cellular receptor may occur during the process of cell purification; $v$ ) a more frequent blood sampling is possible because of the required low amount of blood.

The amount of whole blood in our assays varied from $2.5 \mathrm{ml}$ for in vitro studies (various drug concentrations) to 20-200 $\mu$, depending on the investigated immune function, for the ex vivo studies for a single time point .

We used nonspecific stimuli to activate immune cells rather than specific stimuli, e.g. allogenic spleen cells, because the latter have the disadvantages of being not available for repeat testing and of stimulating only specific immune cell clones [12]. However, triggering of selected immune cell activation pathways is important for a better understanding of the mechanisms of action of immunosuppressants. This allows to devise immune function assays which enable to distinguish drug effects [13]. Thus, we used the following mitogens to assess immune cell functions: i) concanavalin A: $\mathrm{T}$ cell proliferation and surface antigen expression; ii) phorbol 12-myristate 13-acetate plus ionomycin: intracellular T cell cytokine production; iii) actinomycin-D: T cell apoptosis induction; iv) lipopolysaccharide (LPS) (Escherichia coli): intracellular dendritic cell cytokine production.

First, we studied the changes of immune cell functions over time in whole blood stimulated with different mitogen concentrations to define optimal assay conditions. Second, we used optimized assays in vitro to evaluate the drug potencies and efficacies and to differentiate between synergistic and antagonistic effects by adding different drug concentrations alone or in combination to whole blood. Third, in clinical studies we tested the immune function assays to assess the pharmacodynamic drug effects of treated transplant recipients by ex vivo stimulation of whole blood.

\section{Flow Cytometry}

It has been proposed that the flow cytometric investigation of whole blood cell cultures is particularly suitable to observe the pharmacodynamic drug effects with high sensitivity, versatility, and speed $[14,15]$. It can also be used for in vitro testing [16, 17]. In comparison to techniques relying on radionucleotide incorporation to measure inhibition of cell proliferation as an index of drug effect, flow cytometry has been shown to be more specific in measuring drug potencies and efficacies in vivo [18]. Moreover, flow cytometry allows the simultaneous detection of various parameters of immune functions in a small sample volume with a high throughput of cell analysis.

\section{Immune Cell Functions}

$\mathrm{T}$ cell proliferation was measured by simultaneous analysis of proliferating nuclear antigen (PCNA) and DNA content, 
Table 1. Characteristics of cellular differentiations (CD) of $\mathrm{T}$ cell surface antigens

\begin{tabular}{ll}
\hline CD antigen & Function \\
\hline CD11a (LFA-1 $\alpha$-chain) & adhesion (binding (ICAM-1) \\
CD25 (IL-2 $\alpha$-chain) & cell proliferation \\
CD71 (transferrin receptor) & cell proliferation, ferritin metabolism \\
CD95 (Fas antigen, APO-1) & induction of apoptosis \\
CD134 (OX40) & adhesion, co-stimulation \\
CD154 (ligand of CD40) & induction B-cell proliferation and \\
& activation after T-cell contact
\end{tabular}

LFA = Leukocyte function antigen; ICAM = intracellular adhesion molecule.

whereas $\mathrm{T}$ cell activation was detected by the expression of surface antigens playing a potential role in the immune response, e.g. co-stimulation (CD25, CD71), adhesion (CD134, CD154) or apoptosis (CD95) (table 1). Furthermore, T cell activation was detected by the accumulation of intracellular cytokines such as IFN- $\gamma$, TNF- $\alpha$, IL-2 and IL-4 [7, 19]. Additionally, T helper 1 (TH1) and TH2 cytokines (IL-2, IL-4, IL6 , IL-10, TNF- $\alpha$ und INF- $\gamma$ ) were detected in the serum using multiplex bead array analysis [20].

Apoptotic T cells were quantified using the fluorescent annexin $\mathrm{V}$, and the TUNEL assay was used to detect DNA breaks [21].

The myeloid and plasmocytoid dendritic cell subsets in whole blood were determined without stimulation by specific gating strategies to distinguish these two lineages from leukocytes [22]. However, the dendritic cells' production of the intracellular cytokines IL-1 $\beta$, TNF- $\alpha$, IL-6, IL-8 and IL-12 was measured after LPS stimulation of whole blood [23].

\section{Results}

Current practice of immunosuppressive maintenance therapy after organ transplantation consist of combining one basis drug with one adjunctive drug, which have different mechanisms of action during the cell cycle and each bind to a specific target enzyme [24]:

- G0 phase: cyclosporine (CsA) and tacrolimus (TRL), both calcineurin inhibitors;

- G1 phase: sirolimus (SRL) and its derivate everolimus (ERL), both inhibitors of mammalian target of rapamycin;

- S phase: mycophenolate mofetil (MMF), the pro-drug of the active metabolite mycophenolic acid (MPA), inhibitor of ionosine monophosphate dehydrogenase.

Therefore, different drug combinations are possible: CsA and TRL are basis drugs; SRL and ERL are basis drugs as well as adjunctive drugs, and MMF is an adjunctive drug.

\section{In vitro Studies}

In general, assessment of drug effects depends on various factors such as cell type, cell activation status and proliferation and/or apoptosis status and on the assay itself. Nevertheless, our apoptosis assay provided insights into mechanisms of drug monotherapy. Thus, we detected a stronger effect on apoptosis in T cells for MPA compared to SRL or TRL, whereas CsA has no effect [21], confirming a previous study [25].

Evaluating the effects of different drug combinations we showed that overall MPA plus TRL had a greater impact on inhibition of $\mathrm{T}$ cell proliferation, and to a lesser extent on $\mathrm{T}$ cell surface antigens, than all other drug combinations [13]. Our data confirmed that the contribution of MPA is through its substantial antiproliferative effect, but, our data also suggested that MPA mediates its suppression by inhibition of the expression of several $\mathrm{T}$ cell surface antigens as earlier proposed by our study group based on an experimental model [8]. Thus, MPA increased the TRL effect on surface expression inhibition of $\mathrm{T}$ cell activation antigens in a independent synergistic way. Interestingly, the effect of MPA, regardless of the concentrations used, on T cell surface antigens (CD71, CD95, CD134, CD154) in combination with CsA was antagonistic despite an independent synergistic effect of both drugs at the lowest concentrations on CD25.

In contrast to MPA, the effect of SRL in combination with either CsA or TRL on both PCNA and surface antigen expression was initially synergistic but with increasing concentrations antagonistic effects were observed which occurred at the same time in experiments with partial agonists [13]. This is in line with results of studies using human peripheral blood mononuclear cells or whole blood [26, 27]. Even though the differences in the mode of action of these drugs during the cell cycle might satisfactorily explain our results, limitations of drug actions such as competitive binding to the specific immunophilin or a varying active amount of the immunophilin [28, 29] might contribute to our findings, too.

\section{Clinical Studies}

Earlier biomarker assays measured drug target enzyme activity in renal transplant recipients to predict efficacy of CsA [30] and SRL [31] or to evaluate the predictive value of pre-transplant values of MPA enzyme inhibition for the post-transplant outcome [32]. The enzyme assays, in general, do only measure enzyme activity, and not the numerous effects on immune cell function caused by enzyme inhibition. Furthermore, enzyme assays do not measure the net effect on the immune system caused by multiple immunosuppressive drugs with different mechanisms of action. In addition, up to $20 \mathrm{ml}$ of whole blood are required to perform the enzyme assays which restricts its use for repeat measurements or in pediatric recipients.

A commercially available assay measuring ATP levels has been used to investigate the correlation between ATP levels and clinical outcome in renal transplant recipients [33]. Despite the potential of ATP levels to be an early biomarker of 
efficacy, it reflects the overall status of cell metabolism rather than to determine specific insights to drug effects.

$\mathrm{T}$ cell cytokine expression in the serum, intracellularly or at messenger RNA levels, have been evaluated as biomarkers for pharmacodynamic drug measurements in various human transplant studies using ELISA, flow cytometry or PCR as analytic tools [30, 34-40]. The results of these studies differed regarding the relation between the drug pharmacokinetics and drug pharmacodynamics as well as regarding the specification of one to the other cytokine to measure the pharmacodynamic drug effect. This is in line with results of our study about the conversion of a initial immunosuppression of CsA by TRL or SRL [41]. We found that inhibition of cytokine expression correlated with the whole blood TRL concentrations, whereas in the SRL group the increased blood SRL concentration reflected an increase of cytokine inhibition only on day 4 after conversion. The least effect on expression in our study, regardless of the basis immunosuppressive drug used, was detected for IL-4 when compared to inhibitory effects on IL-2, TNF- $\alpha$ and IFN- $\gamma$ expression [41].

In addition, using the multiplex analysis for simultaneous detection of several TH1/TH2 cytokines, we observed a significant decrease of cytokine expression (TNF- $\alpha$, IFN- $\gamma$, IL-2 and IL-6) $2 \mathrm{~h}$ after drug dosing. These drug effects were reflected by significantly increased CsA and MPA concentrations $2 \mathrm{~h}$ after treatment whereas in unstimulated whole blood no drug effects on cytokine production could be observed, underlining the above mentioned advantages of mitogen stimulation of whole blood for quantitating suppression of immune cell function $[8,36]$.

Because of the circadian cycle of cytokine expression, it was suggested to conduct drug application and blood sampling in clinical pharmacodynamic studies at specific time points to avoid that these circadian fluctuations falsify the monitoring of cytokine expression [12].

It was proposed that the pharmacodynamic parameter expression over time might be more appropriate to measure the drug's pharmacodynamics than the measurement at one single time $[8,36]$. Due to the difficulties to obtain blood at several time points, especially in transplant recipients, blood should be analyzed at least at two time points (e.g. before and $2 \mathrm{~h}$ after therapy) to provide information about drug efficacy and about the relationship between pharmacodynamics and pharmacokinetics [42].

In a study in stable HTx recipients treated with a combination therapy of CsA plus MMF, we obtained a high correlation between CsA effects and both blood CsA concentrations and CsA dose. A significant increase in blood CsA concentration $2 \mathrm{~h}$ after dosing led to a significant decrease in PCNA as well as T cell surface antigen expression [41]. Furthermore, it could be shown that CsA blood concentrations were more strongly correlated to $\mathrm{T}$ cell proliferation and surface antigen expression than to $\mathrm{T}$ cell cytokine release. This might implicate to prefer PCNA and surface antigens to cytokines as biomarkers in the combination therapy of CsA and MMF. Additionally, the early antiproliferative effect of CsA might be due to additive effects in combination with the antiproliferative drug MMF as observed in our earlier studies [10,13]. Interestingly, another of our HTx studies [43] showed contradictory results In this study the increased drug concentrations $2 \mathrm{~h}$ after application of either CsA plus MMF or TRL plus MMF did not further attenuate the apoptotic $\mathrm{T}$ cell rate, suggesting a steady state drug effect on $\mathrm{T}$ cell apoptosis.

The potential of $\mathrm{T}$ cell surface antigens as biomarkers to predict the grade of rejection or to predict the pharmacodynamic drug effect was confirmed by other human transplant studies $[35,44,45]$.

In our conversion study the increased blood TRL concentrations over time do not further inhibit expression of CD25 and CD95, but significantly inhibit PCNA and surface antigen CD134 expression from the 3rd day after conversion. Another study in renal transplant recipients showed that, after conversion from CsA to TRL, TRL has a significantly higher impact on expression of $\mathrm{T}$ cell surface antigens than CsA therapy [46].

After conversion from CsA to SRL the blood SRL concentration increased on day 1 and remained stable at days 3 and 4 . But expression of PCNA is not altered by SRL, whereas the expression of CD25 is increased [41]. Our data suggest that SRL dose adjustment relying on blood SRL concentrations do not predict SRL effects on immune cells. This is in accordance with results of our experimental animal study where higher SRL doses led to an increase of blood SRL concentrations without any further inhibition of $\mathrm{T}$ cell proliferation or surface antigens [9].

Over the recent years the importance of dendritic cells for the graft outcome has been realized, determining dendritic cells as ideal therapeutic targets for pharmacological modulation to improve allograft survival [47]. Therefore, we directly enumerated two subsets of dendritic cells (myeloid and plasmocytoid dendritic cells) in the peripheral blood of chronically immunosuppressed HTx recipients.

One characteristic feature of all mature but tolerogenic dendritic cells is their low or absent production of proinflammatory cytokines such as IL-12. Long-term liver transplant recipients with or without low-dose immunosuppressive monodrug therapy had a higher plasmocytoid/myeloid dendritic cell ratio than those with standard immunosuppressive therapy [48].

In our study HTx recipients had a lower subset ratio of plasmocytoid to myeloid dendritic cells than healthy human controls, but after conversion from either CsA/TRL or SRL to ERL the plasmocytoid/myeloid dendritic cell ratio increased [49]. Despite their key role to induce tolerance, plasmocytoid dendritic cells also initiate and maintain the antiviral immune response. Thus, cytomegalovirus infection impairs the immunophenotype and the status of maturation of dendritic cells of HTx recipients [50, 51]. In contrast myeloid dendritic cells are bacteria-activated and mainly produce IL-12 to stimulate 
CD4+ T cells [52]. After LPS stimulation of whole blood of recipients treated with ERL, we found a decrease of IL-12 expression compared that detected in recipients with CsA/TRL or SRL therapy [49].

\section{Conclusion}

For therapeutic drug monitoring biomarkers can be used to predict pharmacodynamic effects of immunosuppressive drugs. However, until now it is not known to what extent biomarkers of immune cell function may be altered by infection or by rejection. Furthermore, it is not clear whether or not baseline values for individual recipients are required nor is an optimal pharmacodynamic target range known [2].

In spite of the above mentioned advantages of whole blood flow cytometry for the assessment of biomarkers of immune cell functions [16], it is foreseeable that further progress in the prospering field of multiplex flow and slide-based cytometry [53-55] will permit to yield more information on more biomarkers of many more cellular functions in different immune cell lineages from smallest amounts of whole blood [56] and to predict pharmacodynamic drug effects more precisely than today [57-59]. Additional future perspectives are based on diagnostic pharmacogenetic assays to identify inherited genetic factors having an impact on the drug response, on the relative susceptibility to drug-drug interactions, or on the predisposition for side effects [60].

\section{Acknowledgements}

Markus J. Barten and Jan F. Gummert were supported by Deutsche Forschungsgemeinschaft grant GU 472/2-3.

\section{References}

1 Kahan BD: Therapeutic drug monitoring of immunosuppressant drugs in clinical practice. Clin Ther 2002;24:330-350.

2 Oellerich M, Barten MJ, Armstrong VW: Biomarkers: the link between therapeutic drug monitoring and pharmacodynamics. Ther Drug Monit 2006;28: $35-38$.

3 Valet G: Human cytome project, cytomics, and systems biology: the incentive for new horizons in cytometry. Cytometry A 2005;64A:1-2.

4 Tárnok A, Valet GK, Emmrich F: Systems biology and clinical cytomics: The 10th Leipziger Workshop and the 3rd International Workshop on SlideBased Cytometry, Leipzig, Germany, April 2005. Cytometry A 2006; 69A:36-40.

$\checkmark 5$ Lenz D, Barten MJ, Hiller S, Tárnok A: Regenerative and predictive medicine of cardiovascular disease: the 9th Leipziger workshop and the 2 nd international workshop on slide based cytometry. $\mathrm{Cy}-$ tometry A 2005;64A:110-114.

6 Sbrana S, Bevilacqua S, Buffa M, Spiller D, Parr MS, Gianetti J, De Filippis R, Clerico A: Postreperfusion changes of monocyte function in coronary blood after extracorporeal circulation. Cytometry B Clin Cytom 2005;65B:14-21.

7 Bocsi J, Richter M, Hambsch J, Barten MJ, Dahnert I, Schneider P, Tárnok A: Transient Th1/Th2 disbalance indicates postoperative effusions and edema after cardiopulmonary bypass in children. Cytometry A 2006;69A:165-168.

8 Barten MJ, van Gelder T, Gummert JF, Boecke K, Shorthouse R, Billingham M, Morris RE: Pharmacodynamics of mycophenolate mofetil after heart transplantation: new mechanisms of action and correlations with histologic severity of graft rejection. Am J Transplant 2002;2:719-732.

-9 Barten MJ, Streit F, Boeger M, Dhein S, Tárnok A Shipkova M, Armstrong VW, Mohr FW, Oellerich M, Gummert JF: Synergistic effects of sirolimus and tacrolimus: Analysis of immunosuppression on lymphocyte proliferation and activation in whole blood. Transplantation 2004;77:1154-1162.
0 Barten MJ, Shipkova M, Bartsch P, Dhein S, Streit F, Tárnok A, Armstrong VW, Mohr FW, Oellerich M, Gummert JF: Mycophenolic acid interaction with cyclosporine and tacrolimus in vitro and in vivo. Evaluation of additive effects on rat blood lymphocyte function. Ther Drug Monit 2005;27: 123-131

11 Barten MJ, Gummert JF, van Gelder T, Shorthouse R, Morris RE: Flow cytometric quantitation of calcium-dependent and -independent mitogen-stimulation of $\mathrm{T}$ cell functions in whole blood: inhibition by immunosuppressive drugs in vitro. J Immunol Methods 2001;253:95-112.

12 Böhler T, Nolting J, Kamar N, Gurragchaa P, Reisener K, Glander P, Neumayer HH, Budde K Klupp J: Validation of immunological biomarkers for the pharmacodynamic monitoring of immunosuppressive drugs in humans. Ther Drug Monit 2007;29:77-86.

13 Barten MJ, Dhein S, Chang H, Bittner HB, Tárnok A, Rahmel A, Mohr FW, Gummert JF: Assessment of immunosuppressive drug interaction: inhibition of lymphocyte function in peripheral human blood. J Immunol Methods 2003;283:99-114.

14 Ramanathan M: Flow cytometry applications in pharmacodynamics and drug delivery. Pharm Res 1997;14:1106-1114.

15 Schlenke P: Leukocyte reduction in blood component supply: the impact of flow cytometry in assessing residual leukocytes. Transfus Med Hemother 2005;32:12-19.

16 Gille C, Orlikowsky T: Flow cytometric methods in the detection of neonatal infection. Transfus Med Hemother 2007;34(3):157-163.

17 Kamprad M, Kindler S, Schuetze N, Emmrich F: Flow cytometric immunophenotyping of umbilical cord and peripheral blood hematopoietic progenitor cells by different CD34 epitopes, CD133, P-glycoprotein expression and rhodamine-123 efflux. Transfus Med Hemother 2007;34(3):195-203.
18 Gummert JF, Barten MJ, Sherwood SW, van Gelder T, Morris RE: Pharmacodynamics of immunosuppression by mycophenolic acid: inhibition of both lymphocyte proliferation and activation correlates with pharmacokinetics. J Pharmacol Exp Ther 1999;291:1100-1112.

19 Suni MA: Detection of antigen-specific T cell cytokine expression in whole blood by flow cytometry. J Immunol Methods 1998;212:89-98.

20 Barten MJ, Rahmel A, Bocsi J, Boldt A, Garbade J, Dhein S, Mohr FW, Gummert JF: Cytokine analysis to predict immunosuppression. Cytometry A 2006; 69A:155-157.

21 Boldt A, Barten MJ, Weiss C, Sagner A, Mohr FW, Gummert JF: Novel apoptosis assay to analyze immunosuppression. Cytometry A 2006;69:158-160.

22 Athanassopoulos P, Vaessen LMB, Maat APWM Balk AHMM, Weimar W, Bogers AJJC: Peripheral blood dendritic cells in human end-stage heart failure and the early post-transplant period: evidence for systemic Th1 immune responses. Eur J Card Thor Surg 2004;25:619-626.

23 Bueno C, Almeida J, Alguero MC, Sanchez ML, Vaquero JM, et al: Flow cytometric analysis of cytokine production by normal human peripheral blood dendritic cells and monocytes: comparative analysis of different stimuli, secretion-blocking agents and incubation periods. Cytometry 2001;46: 33-40.

24 Halloran PF: Immunosuppressive drugs for kidney transplantation. N Engl J Med 2004;351:2715-2729.

25 Takahashi K, Reynolds M, Ogawa N, Longo DL, Burdick J: Augmentation of T-cell apoptosis by immunosuppressive agents. Clin Transplant 2004;18: 72-75.

26 Khanna AK: Mechanism of the combination immunosuppressive effects of rapamycin with either cyclosporine or tacrolimus. Transplantation 2000; 70:690-694.

27 Ferron GM, Pyszczynski NA, Jusko WJ: Genderrelated assessment of cyclosporine/prednisolone/ sirolimus interactions in three human lymphocyte proliferation assays. Transplantation 1998;65: 1203-1209. 
28 Dumont FJ, Melino MR, Staruch MJ, Koprak SL, Fischer PA, Sigal NH: The immunosuppressive macrolides FK-506 and rapamycin act as reciprocal antagonists in murine T cells. J Immunol 1990;144: $1418-1424$.

-29 Kung L, Halloran PF: Immunophilins may limit calcineurin inhibition by cyclosporine and tacrolimus at high drug concentrations. Transplantation 2000; 70:327-335.

30 Grinyó JM, Cruzado JM, Millán O, Caldes A, Sabate I, Gil-Vernet S, Seron D, Brunet M, Campistol JM, Torras J, Martorell J: Low-dose cyclosporine with mycophenolate mofetil induces similar calcineurin activity and cytokine inhibition as does standard-dose cyclosporine in stable renal allografts. Transplantation 2004;78:1400-1403.

-31 Hartmann B, Schmid G, Graeb C: Biochemical monitoring of mTOR inhibitor-based immunosuppression following kidney transplantation: a novel approach for tailored immunosuppressive therapy. Kidney Int 2005;68:2593-2598.

-32 Budde K, Glander P, Bauer S, Braun K, Waiser J, Fritsche L, Mai I, Roots I, Neumayer HH: Pharmacodynamic monitoring of mycophenolate mofetil. Clin Chem Lab Med 2000;38:1213-1216.

33 Cadillo-Chavez R, deEchgaray S, Santiago-Delpin EA: Assessing the risk of infection and rejection in Hispanic renal transplant recipients by means of an adenosine triphosphate release assay. Transplant Proc 2006;38:918-920.

-34 Stein CM, Murray JJ, Wood AJJ: Inhibition of stimulated interleukin-2 production in whole blood: a practical measure of cyclosporine effect. Clin Chem 1999;45:1477-1484.

- 35 Stalder M, Brisan T, Holm B, Haririfar M, Scandling J, Morris RE: Quantification of immunosuppression by flow cytometry in stable renal transplant recipients. Ther Drug Monit 2003;25:22-27.

-36 Haertel C, Fricke L, Schuhmacher N, Kirchner H, Müller-Steinhardt M: Delayed cytokine mRNA expression kinetics after T-lymphocyte costimulation: a quantitative measure of the efficacy of cyclosporin A-based immunosuppression. Clin Chem 2002;48:2225-2231.

- 37 van den Berg AP, Twilhaar WN, Mesander G: Quantitation of immunosuppression by flow cytometric measurement of the capacity of $\mathrm{T}$ cells for interleukin-2 production. Transplantation 1998;65: 1066-1071.

38 Giese T, Zeier M, Schemmer P, Uhl W, Schoels M, Dengler T, Buechler M, Meuer S: Monitoring of NFAT-regulated gene expression in the peripheral blood of allograft recipients: a novel perspective toward individually optimized drug doses of cyclosporine A. Transplantation 2004;77:339-344.
39 Hodge G, Hodge S, Reynolds P, Holmes M: Intracellular cytokines in blood $\mathrm{T}$ cells in lung transplant patients - a more relevant indicator of immunosuppression than drug levels. Clin Exp Immunol 2005; 139:159-164.

40 Sommerer C, Konstandin M, Dengler T, Schmidt J, Meuer S, Zeier M, Giese T: Pharmacodynamic monitoring of cyclosporine a in renal allograft recipients shows a quantitative relationship between immunosuppression and the occurrence of recurrent infections and malignancies. Transplantation 2006;82:1280-1285.

41 Barten MJ, Tárnok A, Garbade J, Bittner HB, Dhein S, Mohr FW, Gummert JF: Pharmacodynamics of T-cell functions for monitoring immunosuppression. Cell Prolif 2007;40:50-63.

42 Brunet M, Campistol JM, Millan O, Vidal E, Esforzado N, Rojo I, Jimenez O, Oppenheimer F, Corbella J, Martorell J: Pharmacokinetic and pharmacodynamic correlations of cyclosporine therapy in stable renal transplant patients: evaluation of long-term target C2. Int Immunopharmacol 2003;3: 987-999.

43 Boldt A, Barten MJ, Sagner A, Mohr FW, Adams V, Dhein S, Gummert JF: The influence of immunosuppressive drugs on T-and B-cell apoptosis via P53-mediated pathway in vitro and in vivo. Transplantation 2006;15:422-1427.

44 Chang DM, Ding YA, Kuo SY, Chang ML, Wei J: Cytokines and cell surface markers in prediction of cardiac allograft rejection. Immunol Invest 1996;25: 13-21.

45 Hutchinson P, Matthew J, Atkins RC, Holdsworth SR: Ex vivo lymphocyte proliferative function is severely inhibited in renal transplant patients on mycophenolate mofetil treatment. Transplant Immunol 2004;13:55-61.

46 Weimer R, Melk A, Daniel V, Friemann S, Padberg W, Opelz G: Switch from cyclosporine A to tacrolimus in renal transplant recipients: impact on Th1, Th2, and monokine responses. Hum Immunol 2000;61:884-897.

47 Hackstein H, Thomson AW: Dendritic cells: emerging pharmacological targets of immunosuppressive drugs. Nat Rev Immunol 2004;4:24-35.

48 Mazariegos GV, Zahorchak AF, Reyes J, Chapman H, Zeevi A, Thomson AW: Dendritic cell subset ratio in tolerant, weaning and non-tolerant liver is not affected by extent of immunosuppression. Am J Transplant 2005;5:314-322.
49 Barten MJ, Garbade J, Bittner HB, Fiedler M, Dhein S, Thiery J, Mohr FW, Gummert JF: Affects of immunosuppression on circulating dendritic cells: an adjunct to therapeutic drug monitoring after heart transplantation. Int Immunopharmacol 2006;6:2011-2016.

50 Varani S, Frascaroli G, Gibellini D, Potena L, Lazzarotto T, Lemoli RM, Magelli C, Söderberg-Naucler C, Landini MP: Impaired dendritic cell immunophenotype and function in heart transplant patients undergoing active cytomegalovirus infection. Transplantation 2005;79:219-227.

51 Burger R, Gerlich W, Gürtler L, Heiden M, Hitzler W, Jansen B, Lefevre H, Lower J, Ludwig WD, Montag-Lessing T, Neumann R, Paessens A, Pauli G, Seitz R, Schlenkrich U, Werner E, Willkommen H: Human cytomegalovirus. Transfus Med Hemother 2005;32:160-166.

52 Lutz M, Schuler G: Immature, semi-mature and fully mature dendritic cells: which signals induce tolerance or immunity? Trends Immunol 2002;23: 445-449.

53 Bocsi J, Mittag A, Sack U, Gerstner AO, Barten MJ, Tárnok A: Novel aspects of systems biology and clinical cytomics. Cytometry A 2006;69A: 105-108.

54 Tárnok A: Slide-based cytometry for cytomics - a minireview. Cytometry A 2006;69A:555-562.

55 Mittag A, Lenz D, Gerstner AO, Tárnok A: Hyperchromatic cytometry principles for cytomics using slide based cytometry. Cytometry A 2006; 69A:691-703.

56 Laffers W, Schlenkhoff C, Pieper K, Mittag A, Tárnok A, Gerstner AOH: Concepts for absolute immunophenosubtyping by slide-based cytometry. Transfus Med Hemother 2007;34(3):188-195.

57 Brockhoff G, Müller S, Sarraf C, Tárnok A: Predictive medicine and clinical cytomics research: resume of the 15th Annual Meeting of the German Society for Cytometry (Deutsche Desellschaft für Zytometrie, DgfZ). Cell Prolif 2006;39:75-78.

58 Tárnok A, Bocsi J, Brockhoff G: Cytomics - importance of multimodal analysis of cell function and proliferation in oncology. Cell Prolif 2006;39: 495-505.

59 Tárnok A, Brockhoff G: Cytomics emerging from cytometry. Cell Prolif 2006;39:335-338.

60 van Gelder T, Hesselink DA, van Hest RM, Mathot RAA, van Schaik R: Pharmacogenetics in immunosuppressive therapy: the best thing since TDM? Ther Drug Monit 2004;26:343-346. 